\title{
Volume 2, Issue no. 4
}

\section{In Search of the Nordic Working Life Model; Introduction to the Thematic Issue}

\author{
I Antti Kasvio, Lena Gonäs \& Egil J. Skorstad
}

\begin{abstract}
- he theme of this issue is "in search of the Nordic working life model." The main reason for choosing this theme is related to the widespread observation that several features of the Nordic institutions of work have been considered atypical when compared with those prevailing in other advanced industrial societies. We are not, of course, the first to make such an observation, and much effort has been spent in order to sort out what we actually talk about when we apply a term like the Nordic model. However, in spite of this effort, we are still toiling with the question of what it is that entitles us to talk about a specific order. Furthermore, if it really exists, will it be able to survive in the face of far-reaching changes that may be expected to take place in the coming decades? On what kinds of resources may it be based in the future?

In the following, we will present some speculations upon such questions while distinguishing between qualities at the societal and organizational level. This may, of course, be considered an artificial differentiation since organizations are a part of society. Nonetheless, we choose to apply this distinction based on analytical reasons. In this way we hope to better illustrate how these entities are linked together in a mutual relationship, thus contributing both to stability and to change. At the end of the introduction, we will give a brief orientation of the content of this issue.
\end{abstract}

\section{Qualities at the level of society}

As noted, the debate on the Nordic model has been marked by an enduring difficulty over definitions. In common parlance, it has become customary to use the term in a very general way, associating it with particularities at the level of society, such as the welfare system, the educational system, and the labor market system. A corresponding partiality has rested among researchers, leaving the question about the qualities of the organization and working life aside. For instance, in the wake of the seminal work of Hall and Soskice (2001), it has become conventional to talk about liberal market economies (LMEs) in contrast to coordinated market economies (CMEs) (Crouch 2005). The former is associated with neoliberal policies involving preferences put on the free operation of the markets, shareholder's interests and deregulation in general, while the latter is characterized by the interference of institutions toward economic affairs. Thus, Hall and Soskice approach their subject in a dualistic way, falling into dichotomies. 
They have been criticized for this on the grounds that their categories are too general, thus missing one of the main point they are trying to embellish, and indicated in the very title of their book: the varieties of capitalism (see, e.g., Gallie 2011). We agree with this objection and may use France and Sweden as an example, two countries that are placed among the CMEs. There are several similarities between the two, but also important differences. One, for instance, is the role played by the labor unions, which is thoroughly different in these two countries because of diverging rates of union membership. These differences affect the power and position of the unions and the role they may play in the shaping of industrial policies and dispute in general.

Hence, more fine-tuned classifications are needed, and we may find examples of them in the works of Amable (2000), Esping-Andersen (1990), and Schmidt (2002). Nevertheless, an important part of the total picture is still missing, especially if we look for qualities and mechanisms that are of importance for the development of working life. We will not be able to complete the depiction here, but instead indicate what we consider at the present time to be the most important societal qualities impinging on working life. These are in particular the following:

- a balanced and cooperative relationship between the state and the powerful representative bodies of employers and employees.

- the prevalence of centralized, coordinated collective bargaining systems.

- a welfare system based on solidarity, involving social security and risk-reducing effects of being hit by industrial restructuring, organizational change, unemployment, illness, etc.

- a prevalence of family-friendly policies, involving measures for parental leave, publicly financed childcare, and individual taxation system, making the conditions more favorable for both women and men to combine work and family.

In this way, the societal idiosyncrasies of the Nordic model in its ideal-typical form contains institutions and policies that act in complementary ways in the sense that they are conditioning and supporting each other in a mutual, supportive, and constructive fashion. We will briefly touch upon some of the potential effects of these institutions later in this introduction.

\section{Emergence of the model}

The institutions referred to above are the result of social, economic, and political processes that have been taking place for more than a century. As a matter of fact, the Nordic economies were relatively undeveloped and poor in the beginning of the $20^{\text {th }}$ century. Nevertheless, the Nordic societies had been among the early adopters of Enlightenment's ideas (Frängsmyr 1981), and a strong working class movement emerged in these mainly rural societies already at that time. Centralized bargaining was adopted as an answer to the worldwide economic crisis of the 1930s (Barth et al. 2003). The main concern then was to see to it that political measures would benefit employment in general and not only those who already were lucky enough to have a job. In Norway, a general agreement between the worker's and employer's associations was passed in 1935, and a similar treaty—-the Saltsjöbaden agreement-was signed in Sweden three 
years later (Fahlbeck 2002; Johansson 1989). The same culture of class collaboration also influenced the social reform policies that were practiced in the Nordic countries after the Second World War. At that time the Social Democratic parties attained a clearly hegemonic position especially in the political life of Sweden, Denmark, and Norway.

The postwar "glorious decades" of strong economic growth, full employment, and expansion of the welfare state (Fourastie 1979) could also be described as the actual golden era of the Nordic working life model. During that period, the Nordic countries proceeded perhaps furthest among all the advanced industrial countries toward turning into homogenous wage-earner societies. The state took it as its task to offer citizens a possibility to acquire at least some kind of a professional or vocational education. Simultaneously, the state was made responsible for creating jobs for everybody and protecting the employees against all possible work-related social risks. The economic policies were programmed to guarantee decent and stable income to all households. The aim of these policies was to secure an adequate level of domestic demand also during economic recessions. Furthermore, it was expected that the demanding and quality-conscious domestic markets would trim the Nordic companies to overcome their competitors also in the global markets.

The Nordic working life model has emerged within this overall societal framework through a long series of innovative policy-making. The adoption of a new kind of industrial relations culture based on mutual trust was just the beginning. After that followed, for instance, the adoption of the so-called Rehn-Meidner model in Sweden during the late 1940s. This was a time when the Swedish export industry expanded rapidly and it had big difficulties in satisfying its recruitment needs. The particular combination of an active labor market and solidarity wage policies was aimed at accelerating structural changes in the economy so that more resources would flow from the less productive sectors to ones with better future prospects (Erixon 2008). Women's possibilities to participate in active working life were promoted for instance through publicly organized care and a systematic stress on gender equality both in education and at the workplace (Hernes 1987). Active occupational safety and health policies were adopted already during the late 1940s (Steen 1995) and a lot of attention has also been directed toward well-designed tools and high-quality working environments.

During the 1960s and 1970s, the Nordic countries advanced into the forefront of the worldwide humanization movement through ambitious and well-publicized sociotechnical experiments and the launching of extensive national workplace development programs (Gustavsen 2007). Furthermore, new legislation was implemented to promote industrial democracy (Byrkjeflot 2001). The liberal and egalitarian values characteristic for the Nordic societies influenced also the manner in which immigrant workers were treated by the labor market authorities and at the workplace (Andersson and Brunk 2009). People with special needs were helped to find their own place in the world of work (Spjelkavik et al. 2011). A strong tradition of social scientific work research evolved alongside these concrete developmental activities (Hvid et al. 2011).

Within this overall framework it is, however, necessary to point out that the Nordic working life model has not evolved in an identical manner and with the same rhythm in all the Nordic countries. Sweden has undeniably been, in many cases, the actual forerunner and also the most followed example, whereas the political situation and the prevailing industrial relations culture in Finland differed clearly from the other Nordic countries during the Cold War era. For instance, the Social Democrats were in Finland 
kept politically rather isolated until the late 1960s and also the trade union movement was split into competing camps (Lilja 1992). In recent times, the structural unemployment rate has been clearly higher in Finland than in the other Nordic countries. This can be partly explained by the considerable job losses that were experienced during the economic recession of the early 1990s.

\section{Qualities at the level of organization}

The Nordic model should not be reduced to some specific institutional arrangements that may impinge on organizational design in general and working conditions in particular. Institutional surroundings are certainly of importance to both, but there is no determinism involved in these relations. Work may perfectly well be organized differently within the same context, as it has been amply demonstrated in studies illustrating the varieties of organizational choice (Davis and Taylor 1979). Even within highly regulated environments, there are potential openings for alternative arrangements, and so is the case for organizations operating in the Nordic context. Theoretically, every one of them may choose their own solution and the question is whether they actually take advantage of these opportunities, thus turning the totality into a thriving variety of organizational constructions.

In general, they seem not to behave in this manner. We are rather witnessing the opposite, at least with regard to undertakings operating within the same kind of business. This trend toward convergence within a particular (national/local) context is demonstrated both by new institutional theorists such as DiMaggio and Powell (1983) and by societal effect theorists like Maurice et al. (1982). According to them, the idiosyncrasies of a particular society affect organizations in profound ways, leading to a convergence within the national border and a corresponding divergence across borders. The domination of similar solutions at the local level may also be the result of the combining effect of the relentless search for ever-increasing productivity and the dispositions of fumbling managers afraid of displaying their ignorance regarding the latest organizational fashion (Sennett 1999). We may be witnessing processes that are often referred to as "mimetic isomorphism" (DiMaggio and Powell 1983).

Yet there are cases of exceptional circumstances where signs of departure from traditional trajectories may take place. In Norway, one such event took place in the middle of the 1960s when the major representative bodies of the industrial society united in a collective effort at changing traditional ways of organizing working life. The entrepreneurial force behind the original initiative was Einar Thorsrud, who succeeded in instilling the idea among important figures in the business community that participation and democracy at work would benefit all parties, employers, as well as employees. Employees, it was argued, would benefit from improved working condition. Employers would benefit from the creativity and commitment that would be aroused by workers experiencing these new conditions featured by varied work, new challenges, and autonomy.

This initiative was launched at a time when Taylorism dominated the common understanding of how to organize work, at least in the manufacturing circles (Guillén 1994). In line with this strand of thought, work ought to be divided into routine jobs and planned and controlled according to time and motion studies. Workers operating 
within these regimes were deskilled and expected to follow the principles embedded in the physical arrangements; accordingly there was no room for individual discretion. Thorsrud's initiative represented a departure from this practice, in particular when it came to questions of skills and autonomy. The basic idea was to reinstall the worker as the creative and productive force in the realm of production. Autonomy should make conditions favorable for the utilization of local discretion, and the varied work and improved qualifications should see to it that commitment actually was to be used in a productive way. This kind of reasoning was inspired by sociotechnical theory, a particular strand of general open-system theory developed in connection with the coalmine experiments carried out by researchers at the Tavistock Institute in the UK in the 1950s (Emery 1978). In this case, the emphasis was on the social and the technical systems that, according to the arguments, had to be prioritized when organizational design took place (Brown 1992, Emery 1978; Rose 1975). If not, organizational performance would suffer, because of either discontent employees or malfunctioning technology. In practical terms, this kind of thinking led to organizational solutions involving autonomous groups; as members of such groups ordinary employees were supposed to have what they yearned for most of all-varied work and sufficient freedom to decide on workrelated matters for themselves. Accordingly, such arrangements were considered to be the proper answer to what was later referred to as the crises of Taylorism, which were about worker resistance and organizational inability to respond to changing environments in a flexible way (Skorstad 2002). The attention the initiative aroused at the beginning was unprecedented and the expectations it fostered among its originators was nearly unbounded; this was considered to be the advent of a new paradigm of work (Thorsrud and Emery 1970).

It would be wrong to claim that this turned out to be true. Certainly there were several cases of organizational transformations taking place in the aftermath of the first experiments. The particular way of organizing work even rose to prominence when the Swedish carmaker Volvo decided to organize its assembly part of production along the lines of the new principles (Sandberg 1995). However, the grand expectation of a historical transition was not fulfilled; the main part of working life seemed to continue its operations along the lines they were accustomed to follow.

Despite this it would be equally wrong to claim that the original initiatives were part of a passing fashion and nothing more. Even though the pioneers failed in their ambitions of laying the foundation for extensive reforms, they were more successful in putting the question of democracy at work on the agenda of industrial relations. Gradually, questions related to participation or autonomy at work was no longer considered irrelevant, or worse, set under taboo. From now on, it developed into an important subject that was related both to the quality of work and to the functioning of organizations. Eventually, these changing sentiments led to formal provisions, such as the Worker Protection and Working Environment Act from 1977, and the Agreement upon Technological Change that was adopted as a part of the Basic Agreement in 1975 in the case of Norway. Both included passages on compulsory rights for workers to have a say in matters such as organizational change in general and technological implementations in particular. Both also included prescriptions for how to organize such participation, e.g., through bodies representing those who were supposed to be affected. The Act of Codetermination in Sweden (MBL) and the Law on Board were regulations that formalized and institutionalized cooperative forms of participation. 
These provisions were implemented in order to work as buffers toward organizational changes that might affect employees in negative ways. Compulsory participation was expected to moderate or even lead to dismissal of initiatives that could be considered detrimental for working conditions. It is, however, important to note that the democratic arrangements were originally conceived as ends in themselves and not as measures to avoid unwanted consequences of organizational change. This also applied to ordinary, daily operations; autonomy at work was seen as an imperative quality of the new regime.

Nevertheless, the economic downturn of the 1980s turned the question of democracy into an instrumental direction, mainly for pragmatic reasons. The downturn made organizational change imperative for survival, and managers had already experienced that participative practices had the potential of facilitating the implementation of such transformations. In a survey from 1984, managers confirm this kind of positive attitude toward democracy at work (Nilssen 1984). It leads, they say, to improved cooperation, growing involvement, and declining resistance toward organizational change. In this way, their sentiments proved to be in line with the result of the classical experiment of Coch and French (1948) where they demonstrate the conflict-reducing capacity of participatory schemes.

Since then, participation at the level of organization has for the most part been considered as a comparative advantage, and there are in particular three conditions that make up these advantages. First, participation may foster satisfaction and creative involvement among ordinary employees. Second, it may reduce resistance toward change. Third, it may lead to better solutions, both in daily operations and in processes involving organizational change. Participation may, of course, be applied out of manipulative intentions, and if that is the case, employees will hardly act as indicated above. However, when used in a committed way, it may foster a cooperative culture and pliable organizations. In an ideal-typical sense, this is an important part of the comparative advantage of the Nordic working life model. Skillful and autonomous employees may demonstrate cooperative creativity, thus contributing to the emergence of flexible undertakings that may operate efficiently under turbulent conditions.

\section{Contemporary challenges}

The Nordic order commented upon above has been challenged during the recent decades by an influx of contesting ideas of how to organize relations, both at the societal and at the organizational level. These ideas are mainly part of a neoliberal ideology that involves deregulation for the benefit of the free flow of products, labor, and capital. Furthermore, it involves the creation of institutional frameworks to secure and support such a flow and a shift in power from the level of managing directors to the shareholders and corporate headquarters operating anywhere in the world (Harvey 2005). All this, it is argued, benefits ordinary citizens who may find themselves empowered-with the freedom to choose according to their individual needs and preferences. In such settings, flexibility at the level of organizations becomes imperative. Those who are able to act in a pliable way may prosper. However, those who cannot may find themselves in deep trouble. In short, organizational flexibility is considered to be the very key to operational success for any establishment. 
Throughout the years, the quest for increased flexibility has followed different strategies, and they may be classified into four categories (Skorstad and Ramsdal 2009). The first one involves employment practices that may have a dividing effect upon the workforce, as demonstrated by Atkinson (1984) and others. ${ }^{1}$ Another one is related to structure, ${ }^{2}$ a third one to organizational culture, ${ }^{3}$ and a fourth one to the construction of industrial networks. ${ }^{4}$ As strategies for obtaining flexibility, they differ in their nature, but they all have in common that they embody the most essential features of the neoliberal paradigm: the construction of the customer as the major agent impinging on the transactions in question, the marketization of these transactions, and the emphasis on instrumental measures in order to create pliability and consent.

The most prominent example of these new solutions is focused on in the notion of the "lean" organization. This particular concept became common knowledge in the wake of the seminal work of Womack et al. (1990), but the origin of its underlying logic dates back to the initiatives of the carmaker Toyota during the 1960s and 1970s in turning their planning and production system into a responsive, real-time operational system. Today, the prominence of the system rests partly on its comprehensible logic, a quality otherwise arguably underdeveloped within the field of organizational studies. Moreover, its practical applicability has been amply demonstrated on several occasions, and this, together with its appealing rationality, has made it a popular subject among organizational consultants who have demonstrated great eagerness and creativity in turning "lean thinking” into a profit-making business. Since its inception, the original organizational concept has been modified, reshaped, and reinvented in numerous, slightly different variants, each of which has been promoted because of its superiority, not only within the realm of car manufacturing but also in both private and public establishments. Agile manufacturing, business process reengineering, quick response, and the malleable phenomenon of new public management and its various kinds of performance management systems are some examples of such reinvented regimes. Each of them claims to be unique. In reality, however, they are all embedded in the same kind of logic.

The ideal-typical version of the lean system is exemplary as an illustration of how these new organizational formulas are expected to work (Skorstad 1994/2006). Production or services are organized in a process-oriented way. Similar products/ services are separated along different lines. Each of them is balanced to prevent piling up or delayed deliveries at each individual operation. Operations take place according to real demands. Buffers are eliminated and employees are multi-skilled to allow for job rotation. Unproductive time is kept to a minimum. The main point is to operate in a responsive and lean way; the emphasis is on individual operations and their mutual attunement in order to respond to shifting market demands in a smooth and pliable way. Due to this increased responsiveness and the logic of the system at large, market mechanisms are no longer restricted to transactions crossing the border between the environment and the firm. They make their entrance into the system as well and become the hallmark of the organization itself. In its most refined form, each individual operator turns into a producer and a customer at the same time (Knights and Willmott 2000). The same thing may happen at aggregate levels: among groups, departments, and divisions. Through such processes, then, the logic of the market is promoted to prominence and given precedence in most parts of working life, in manufacturing, in retail businesses, in transportation, in hospitals, in education, and in the delivery of 
social services in general. As we may see, we are far from the conditions considered imperative for the functioning of autonomous groups, which may be considered as one of the hallmarks of the Nordic working life model. Independency is replaced by dependency.

\section{Conflicting principles}

In turn, this means that organizational designers of today are facing conflicting principles when it comes to the question of what is considered to be the best solution. Indeed there is emphasis in both camps on the importance of constructing flexible organizations. There is also a common understanding of why this is imperative. Recommendations on how flexibility should be attained, however, are diametrically opposed. The proponents of the Nordic order argue that working conditions in general-and autonomy and participation in particular-are key to the coveted quality. This is because they have faith in the positive correlation between satisfied employees and their commitment and creative involvement. Employees who are treated well and trusted to employ their autonomy will respond in a positive way, demonstrating their willingness to use their local knowledge and ingenuity in a collective effort at reaching official goals. It should be added that these are sentiments shared by a wider audience beyond the sociotechnical tradition. We may find similar arguments both in classical studies and in contemporary works. ${ }^{5}$

Compared with this, the measures promoted by the neoliberal camp are of a quite different character. Neoliberals, commentators claim, are profoundly suspicious of democracy (Harvey 2005). Democratic procedures are mainly considered as time and cost-consuming activities that should be replaced by governance by experts or elites, the sooner the better. At the organizational level, therefore, market mechanisms are considered a far better answer to the challenges of running operations in a smooth and efficient way (Connell et al. 2009). Moreover, performance management systems embodying specified targets, rules, scripts, frequent appraisals, and performance pay schemes are judged appropriate (Edwards and Wajcman 2005). These mechanisms are the result of the beliefs that there is a need for tailored means in order to govern and control human behavior because of conflicting interests embedded in the organization.

In this way, organizational designers are facing conflicting beliefs in how to succeed, and the latter indicated above represents a departure from the principles associated with the Nordic working life model in important ways.

\section{Is the Nordic working life model still alive?}

In a similar way, established institutions at the societal level have been exposed to criticism and claims of transformations. Perhaps the most critical period for the Nordic welfare societies arrived during the late 1980s and early 1990s. Especially Finland and Sweden suffered major losses after the collapse of the Soviet Union and the breakout of a deep economic recession (Jonung and Hagberg 2005). Several commentators started to speculate whether the Nordic welfare states would also face a similar kind of fate 
as was experienced a few years earlier by the People's democracies in the Central and Eastern Europe (The Economist 1993). Claims for an extensive reform of the existing institutional arrangements were presented also within the Nordic countries themselves (e.g., Lindbeck et al. 1993).

In reality, the Nordic model has appeared much more resilient than many observers have expected. These countries were for instance able to recover relatively quickly from the economic difficulties experienced during the early 1990s, and shortly thereafter they advanced into the worldwide forefront of the new information technology revolution (Castells and Himanen 2002). The Nordic countries did not suffer very much from the consequent collapse of the financial bubble, and nowadays-after the crisis of 2008-09-the Nordic countries (except Iceland because of the collapse of its banking system) are among the best performing of all advanced industrial societies. Their economic growth rates are quite good in comparison to the other West European countries, the unemployment rates are clearly below the average European levels, and both their foreign trade and public finances are in a much better balance than in most other advanced industrial countries. In recent times, the Nordic countries-together with the Netherlands-have received much praise for their "flexicurity" policies. This policy encourages citizens to take risks and to behave in a flexible manner in the labor markets by securing the existence of well-functioning, basic social safety networks (Wilthagen and Tros 2004).

Taking into account the neoliberal trends described earlier, it is possible to ask whether the Nordic countries are still, at present, actually following the basic principles of the Nordic working life "model." Some recent events and developments may give grounds for raising this question. For instance, the Swedish National Work Life Institute was closed down by the bourgeois government in 2007. Swedish employers have wanted to disengage themselves from the earlier forms of three-partite cooperation with the unions and the state. Income differences have started to widen also in the Nordic countries during the 2000s (OECD 2011). Anti-immigrant attitudes have gained increasing support in a manner that does not fit very well with the region's traditional liberal and egalitarian values. All these trends make the overall picture of the Nordic model much more nuanced, and they relativize the image of these countries as some kind of Social Democratic ideal societies. Also the voting behavior of their citizens has become more volatile in recent times (as an interesting commentary about recent developments in Sweden, see The Economist 2012).

\section{Some of the model's key outcomes}

Despite these kinds of reservations, we can see from recent statistics that the Nordic institutions of work are currently functioning relatively well in comparison to the other advanced industrial countries. For instance, of the Nordic population belonging to the age group from 15 to 74 years, 25-29 percent had tertiary and 38-50 percent secondary-level education in 2010 (Haagensen 2011). The Nordic countries have also been able to mobilize their human resources rather broadly. The employment rates of workage people (20-64) varied in 2011 from 73.8 percent in Finland to 80.6 percent in Iceland, whereas the average European Union rate was 68.6 percent. Especially women's employment rates are considerably higher than in other advanced industrial countries. 
The harmonized and seasonally adjusted average unemployment rates varied in August 2012 from 3.0 percent in Norway to 8.0 percent in Finland, whereas the average rate in the European Union was 10.5 percent (Eurostat 2012).

It is somewhat more difficult to compare the actual competitiveness or productivity of Nordic workplaces to those levels that are achieved in other advanced industrial countries. One reason for this is that a relatively large part of the labor force within the Nordic countries is employed in the public sector, which is normally left outside international productivity comparisons. However, we may assume based on the existing information that especially the hourly productivity in the Nordic countries does not remain very much below the levels achieved in the United States. Nevertheless, the picture becomes increasingly unclear if we look at the recent labor productivity growth trends. After the 2008 recession, the labor productivity has trended clearly upward in Sweden; in Denmark and Norway productivity growth has been more sluggish, whereas Finland experienced a clear drop as a consequence of labor hoarding (for an overview of recent productivity developments in Europe, see, e.g., OECD 2012a; see also Cette et al. 2007).

The quality of working life in the Nordic countries is currently, according to most criteria, high in comparison to the other advanced industrial countries, but the differences are not big (see, e.g., Green 2005, EU Commission 2008, Gallie 2011, Parent-Thirion 2011, and Oinas et al. 2012). Among the most distinctive features are decent opportunities to develop one's skills and to have a say on how work is carried out. One exception from the generally positive picture is that the levels of work intensity experienced by Nordic workers are rather high in comparison to other advanced industrial countries (EU Commission 2008, 159).

When looking at the material rewards gained from work, we can see that especially in Norway and Denmark the present wage levels are high in comparison to the other advanced industrial countries and they are not low in Sweden and Finland, either. However, taking into account the heavy taxation and the high costs of living, the actual purchasing powers of the Nordic households are not particularly high. The relatively small differences in the levels of salary between various groups of wage earners mean that for instance the salaries of male professionals may appear in the eyes of potential immigrants modest in comparison to some other advanced industrial countries. On the other hand, the category of working poor is almost nonexistent in the Nordic countries (Brady 2011).

One important characteristic feature of Nordic societies is the culture of relatively few working hours. For instance, in 2010, the number of actually worked working hours varied from 1414 in Norway to 1697 in Finland and Iceland, whereas the OECD average was 1794 hours (OECD 2012b). This tells us that the Nordic citizens can enjoy from larger amounts of leisure time than for instance their U.S. colleagues. They also have better possibilities to combine work and family obligations with each other.

\section{Perspectives for the future}

Despite their fairly strong initial positions, the Nordic countries must also stretch their resources to the outmost if they want to succeed in the coming decades' tightening competition over investments and jobs. A clear warning sign has been the extent to which 
the Swedish automobile industry and the Finnish telecommunications cluster have lost their earlier positions to more successful competitors. New growth industries will be needed to replace the older ones in order to maintain the required levels of economic activity. The Nordic countries must also keep taxation and public expenditures within reasonable limits; they have to renew their public sector activities, further strengthen the overall competitiveness of their economies, and find new ways to promote social solidarity between the different social strata. Simultaneously, the Nordic societies must strive to spare natural resources and to reduce their greenhouse gas emissions and other harmful environmental effects to more sustainable levels.

According to many observers, the fast expansion of human economic activities has already reached clearly beyond our planet's carrying capacities and in future we will be moving toward desperate struggles over the still remaining natural resources and livable spaces in the midst of dying ecosystems (see, e.g., Brown 2011, Hengeveld 2012). The main task both in the Nordic countries and in other parts of the world would therefore be to find ways to satisfy essential human needs and to live well without overutilizing the planet. A new industrial revolution is said to be needed in order to reach toward a more lasting civilization. Taking into account the Nordic countries' former active role in efforts to promote sustainable development and the sustainability strategies adopted by many Nordic companies, it has been suggested that the Nordic societies ought to be at the forefront also in this transformation process. One important dimension is the building of more sustainable systems of work (see, e.g., Docherty et al. 2008). The Nordic trade unions have, as a matter of fact, already committed themselves to such a strategy (NFS 2012).

Because of their geographical location, the Nordic countries may be able to pass through the coming environmental turbulences with relatively minor losses (Smith 2011). But just because of this the Nordic countries must be prepared to provide aid to those-mainly Southern-societies that are forced to renew their institutions of work in much more difficult conditions.

\section{The following articles}

Pertti Kettunen opens our selection of articles with a reinterpretation of the historicity of the Nordic model. He states that in the existing welfare-state and industrial-relations literature, the particular pattern of social change and reform in the Nordic countries has sometimes been misinterpreted partly because of an inexact use of terms which do not necessarily describe adequately how certain arrangements have functioned and been understood in the Nordic context. He addresses, for instance, the well-known thesis concerning the Nordic "politics against markets," which is said to have led to a high degree of "decommodification" of labor. In actual fact, the Nordic countries have been very much labor market-oriented in their social and economic policies in which the labor market parties—unions and employer organizations—have acted as regulators.

Furthermore, he stresses the significance of the specific way in which the roles and relationships between the state, individuals, and the civil society have been functioning. In this regard, the Nordic countries have differed very much from the other CMEs. Kettunen also discusses the significance of the new developments that have taken place especially since the 1980 s when the Nordic societies were integrated into parts of a 
new global economy. This process has to a large extent destroyed the old-at least imagined-symmetrical relationships between the different labor market partners and opened gates toward a more hegemonic primacy of the management perspective. It has also led to a significant "institutional conversion" in which the traditional defenders of the welfare state and the system of collective agreements are trying to legitimize their efforts in terms of competitiveness, whereas those in favor of more market-oriented policies and stricter budgetary discipline present their agenda as a means to save the welfare state.

Jan Heiret focuses in his analysis on the development of working life and industrial relations in just one of the Nordic countries-Norway. He stresses that behind the current picture of a prosperous system based on a harmonious dialogue between workers, employers, and state lies a rather complex historical development in which despite an apparent continuity of institutions, the latter's content and social roles have altered significantly during the different stages of the model's development. The author postulates that it is possible to talk about three different Norwegian models, the first of which culminated together with the signing of a first general agreement between LO and NAF, the central trade union and employer organizations. It consisted of a fragile compromise between the different actors and their contradictory interests, and significant inequalities and cultural differences still prevailed in Norwegian working life. The second model matured in the late 1970s as a much more developed and integrated industrial relations system in which both the private and the public sector were committed to promoting the growth of private industries and the further development of the welfare system. A lot of attention was paid also toward industrial democracy and sociotechnical development of work organizations. Since then a third model has been emerging, which is characterized by both efforts toward liberalization and a political determination to promote equal and inclusive working life also in the restructuring processes that are going on at the private and public sectors. Even if Heiret's analysis is limited to Norwegian developments that are to a large extent rather unique, it is quite evident that similar kinds of adjustments have also taken place in all Nordic countries involving somewhat different kinds of actors, other kinds of strategies, and leading to varying series of "models."

Anita Nyberg is the author of the third article in our issue that approaches the Nordic working life model from a historical point of view. She focuses on the development of gender equality policies in Sweden during the last half century. She starts from the 1960s' debates about whether women's participation in working life should be supported mainly by building more publicly financed child care centers or by distributing more direct monetary support for the parents of small children so that they can organize the needed support as they like. Varying arguments were presented in favor of the different solutions and at least some of the ideological divergences have pervaded to the present. Several reforms have been introduced in Sweden since then in order to promote gender equality in working life, and men's and women's employment rates have indeed come closer to each other, but this has not led yet toward any significant reductions in the traditional inequalities with regard to unpaid household work. The author concludes that the future gender equality and work-family reconciliation policies ought to direct their measures equally to women and men, mothers and fathers if the aim is to achieve real changes in the prevailing gender orders in both spheres-paid and unpaid-of work. Also with regard to this analysis we can conclude that many 
of those debates which the author describes in the Swedish context have been very similar to those that have been going on in the other Nordic countries as well, even if the timing and actual content of the reform measures proposed and implemented vary to a certain extent.

Peter Nielsen, René Nesgaard Nielsen, Simon Grandjean Bamberger, Jørgen Stambus, Kirsten Fonager, Øyvind Omland, Anelia Larsen, Anker Lund Vinding, and Pia Ryom proceed from historical analyses toward more contemporary examinations of the Nordic working life model in an empirical article about the capabilities of innovation in Danish companies. They start from an assumption that even if the tightening global competition pushes the companies to lay more stress on innovations in all advanced industrial countries, the collaborative industrial relations systems characteristic of the Nordic countries have a clear impact upon the way in which the business companies respond to this challenge. The analysis is based on a representative survey covering more than 600 Danish firms. Without going into any details of the extensive and content-rich analysis, we can cite the authors' conclusions according to which a large part of the firms examined had launched at least some kinds of innovations on the market during the two-year period that was covered in the analysis. There was a strong linear correlation between the priority given to innovation and the actually realized product or service innovations. Competence development and organizational configurations encouraging learning were positively and significantly related to the companies' innovative capabilities, whereas codetermination seemed to have only an indirect effect upon that feature. The authors complete their study with a fresh analysis about the ways in which the Danish companies have experienced the newest financial crisis. Here the empirical results show that a milieu of cooperation and codetermination is of relevance in building dynamic capabilities and realizing them as new innovations also in these very challenging conditions. Altogether, the analysis thus seems to lend support to assumptions made in the earlier more historically oriented analyses about the positive contributions of well-organized industrial relations to the global competitiveness of firms.

Hege Eggen Borve and Elin Kvande analyze the impacts of globalization upon the Nordic model from a somewhat different angle. They examine how an international top-level professional company with Norwegian founders understands and applies the Nordic model in their operational units that are situated in Norway and in the United States. In their qualitative analysis based mainly on interviews, the authors come to a conclusion that most of the ethnic Norwegian managers and employees share an understanding of equality, freedom, and empowerment as important characteristics of their organizations, whereas their ethnic American counterparts have a tendency to behave according to the norms of a more hierarchical organizational culture. Certain difficulties emerged for instance in following the Nordic work time regimes in a business in which competition is extremely hard and in which borderless working is the predominant norm. Reading the analysis easily leads to a conclusion that similar kinds of cultural adjustment problems become increasingly common when the work done in Nordic countries or in Nordic companies are further integrated into parts of wider productive networks.

Tomi Oinas, Jouko Nätti, Timo Anttila, and Armi Mustosmäki look at the development of job quality in Europe and the possible distinct features of the Nordic countries on the basis of the European Working Condition Surveys collected between 1995 and 
2010. They focus mainly upon perceived trends in job quality, which is analyzed in three dimensions-skills, autonomy, and work effort. Based upon a carefully conducted statistical analysis, the authors conclude that their analysis partly supports the earlier claims of high quality of working life in the Nordic countries, but with some important qualifications. Denmark stands out from the other European countries with regard to both the overall level of job quality and its recent development trends, whereas Finland and Sweden are not very different from the UK and other LMEs. The Liberal-Nordic convergence can be explained both by the degradation of job quality in the Nordic countries and by improvements in the liberal regime. This result undoubtedly gives some food for thought for instance in discussions about the Nordic working life model's future sustainability.

Kristina Håkansson, Tommy Isidorsson, and Hannes Kantelius open in their article an interesting perspective to flexibility, in recent times perhaps the most advertised feature of the Nordic working life model. Their analysis focuses upon the employees' perceptions about their work situation in three Swedish temporary work agencies delivering mainly white-collar workers. Taking into account the fact that in Sweden open-ended contracts are regarded as the normal type of employment contract also in temporary agency firms, the latter should embody the best aspects of flexicurity: the firms can get some extra human resources from an agency very flexibly at the same time as the employees can enjoy from the security provided by the open-ended contracts they have with their agency. In practice, however, the temporary agency workers do not experience their position to be as secure as employees in traditional permanent employment relationships. Among the agency workers, perceived security increases, e.g., with age, training, and the extent to which the workers are integrated with the activities of the hiring firm. Simultaneously, the experience of security is related positively with the commitment of employees. Overall, it seems that building these kinds of triangular relationships between ordinary firms, work agencies and individual employees are still searching their place in the Nordic working life. They may be instrumental in promoting some aspects of flexibility, but at the same time their expansion may lead to new kinds of insecurities.

The last article written by Tora Dabl takes us to a very exotic part of the Nordic countries, the Faroe Islands in the middle of the North Atlantic with only about 50,000 inhabitants. The author analyses the way in which this autonomous island has created an unemployment insurance system, which has some atypical characteristics with regard to those prevailing elsewhere in the Nordic countries but which at the same time can be seen as an outcome of the deep-rooted Nordic negation tradition. The system is rather unique in the sense that it is based on obligatory membership, it is integrated with job centers, and it is administered by a board consisting of labor market representatives. The author sees in her analysis-based on interviews and documentary analysis-the emergence of this system as a result of efforts to ensure this system's autonomy from political influence even if it remains still somewhat open to what extent the labor market partners will actually have influence upon the system's future development. Even if the subject of this article is indeed very limitedwe can think the number of people who each year really receive contributions of this system-the article serves as a beautiful example of the significance of localism that can be seen as one of the most essential features of the Nordic societies and cultures also more generally. 


\section{References}

Ackroyd, S. (2009). The re-organization of manufacturing and the emergence of a flexible economy in the UK. In Skorstad, E. J. \& H. Ramsdal (eds), Organizational Flexibility and the New Working Life. A European Perspective. Farnham: Ashgate, 187-208.

Amable, B. (2000). Institutional complementarity and diversity of social systems of innovation and production. Review of International Political Economy, vol. 7, no. 4, 645-687.

Andersson, P., \& T. Brunk (2009). Occupational Promotion of Migrant Workers. Dublin: European Working Conditions Observatory.

Atkinson, J. (1984). Manpower strategies for flexible organizations. Personnel Management, August, 28-31.

Barth, E., K. Moene, \& I. Wallerstein (2003). Likhet under press: Utfordringer for den skandinaviske fordelingsmodellen. Oslo: Gyldendal Akademisk.

Becattini, G., M. Bellandi, \& L. De Propris (eds) (2009). A Handbook of Industrial Districts. Cheltenham UK: Edward Elgar.

Benton, L. (1992). The emergence of industrial districts in Spain: Industrial restructuring and diverging regional responses. In Pyke, F. and W. Sengenberger (eds), Industrial Districts and Local Economic Regeneration. Geneva: ILO, 48-86.

Best, M. (1990). The New Competition. Institutions of Industrial Restructuring. Cambridge: Polity Press.

Beynon, H. \& T. Nichols (eds) (2006). The Fordism of Ford and Modern Management. Fordism and Post-Fordism. An Elgar Reference Collection Vol. I. Cheltenham, UK: Edward Elgar.

Bradley, H. (2009). Whose flexibility? British employees' responses to flexible Capitalism. In Skorstad, E. J. \& Ramsdal, H. (eds), Organizational Flexibility and the New Working Life. A European Perspective. Farnham: Ashgate, 79-96.

Bradley, H., M. Erickson, C. Stephenson, \& S. Williams (2000). Myths at Work. Oxford: Polity Press.

Brady, D. (2011). Comparing European Workers: Experiences and Inequalities. Bingley: Emerald Group Publishing Limited.

Brown, L. R. (2011). World on the Edge: How to Prevent Environmental and Economic Collapse. Washington DC: Earth Policy Institute.

Brown, R. K. (1992). Understanding Industrial Organisations. Theoretical Perspective in Industrial Sociology. London: Routledge.

Brusco, S. (1990). The idea of the Industrial District: Its genesis. In Pyke, F., G. Becattini \& W. Sengenberger (eds), Industrial Districts and Inter-Firm Co-operation in Italy. Geneva: ILO Publications, 10-19.

Burns, T., \& G. M. Stalker (1961). The Management of Innovation. London: Tavistock.

Byrkjeflot, H. (ed) (2001). The Democratic Challenge to Capitalism. Copenhagen: Samfundsliteratur.

Capecchi, V. (1990). A history of flexible specialisation and industrial districts in EmiliaRomagna. In Pyke, F., G. Becattini \& W. Sengenberger (eds), Industrial Districts and Inter-Firm Co-operation in Italy. Geneva: ILO Publication, 20-36.

Castells, M., \& P. Himanen (2002). Information Society and the Welfare State: The Finnish Model. Oxford: Oxford University Press.

Cette, G., M. Fouquin, \& H.-W. Sinn (eds) (2007). Divergences in Productivity between Europe and the United States: Measuring and Explaining Productivity Gaps between Developed Countries. Northampton, MA: Edward Elgar Publishing.

Coch, L., \& J. P. French (1948). Overcoming resistance to change. Human Relations, vol. 1, 512-532. 
Connell, R., B. Fawcett, \& G. Meagher (2009). Neoliberalism, New Public Management and the human service professions: Introduction to the Special Issue. Journal of Sociology, vol. 45, no. 4, 331-338.

Coriat, B. (1991). Penser à l'envers. Paris: Christian Bourgois Editeur.

Crouch, C. (2005). Capitalist Diversity and Change. Recombinant Governance and Institutional Entrepreneurs. New York: Oxford University Press.

Davis, L. E., \& C. Taylor (eds) (1979). Design of Jobs. Santa Monica, CA: Good Year.

Deal, T. E., \& A. A. Kennedy (1982). Corporate Cultures: The Rites and Rituals of Corporate Life. Harmondsworth: Penguin Books.

DiMaggio, P., \& W. Powell (1983). The iron cage revisited: Institutional isomorphism and collective rationality in organizational fields. American Sociological Review, vol. 48, 147-160.

Docherty, P., M. Kira, \& A. B. (Rami) Shani (eds) (2008). Creating Sustainable Work Systems: Developing Social Sustainability, 2nd edition. London: Routledge.

Dohse, K., U. Jürgens, \& T. Malsch (1985). From Fordism to Toyotism? The social organization of the labor process in the Japanese automobile industry. Politics and Society, vol. 14, no. 2, 115-146.

The Economist (1993). 'Farewell Nordic Welfare'. The Economist, October 23rd.

The Economist (2012). 'Sweden: The New Model; a bit more unequal, a lot more efficient'. The Economist, October 11th.

Edwards, P., \& J. Wajcman (2005). The Politics of Working Life. Oxford: Oxford University Press.

Emery, F. (1978). The Emergence of a New Paradigm of Work. Centre for Continuing Education: The Australian National University.

Erixon, L. (2008). 'The Rehn-Meidner model in Sweden: its rise, challenges and survival'. Nationalekonomiska institutionen, Working Papers 2/2008.

Esping-Andersen, G. (1990). The Three Worlds of Welfare Capitalism. Cambridge: Polity Press.

EU Commission (2008). Employment in Europe 2008. Brussels: European Commission

Eurostat (2012). Statistical database tables. http://epp.eurostat.ec.europa.eu/portal/page/ portal/eurostat/home/(reading 30.10.2012).

Fahlbeck, R. (2002). Industrial relations and collective labour law: Characteristics, principles and basic features. Scandinavian Studies in Law, vol. 43, 87-133.

Fevre, R. (2007). Employment insecurity and social theory: The power of nightmares. Work, Employment and Society, vol. 21, no. 3, 517-535.

Fourastié, J. (1979). Les Trente Glorieuses ou la révolution invisible de 1946 à 1975. Paris: Fayard.

Frängsmyr, T. (1981). The Enlightenment in Sweden. In R. S. Porter (ed), Enlightenment in the National Context. Cambridge: Cambridge University Press, pp. 164-175.

Gallie, D. (2011). Production Regimes, Employee Control at Work and Skill Development. Presentation at the Work Research Conference, Tampere, Finland, 4th November.

Gallie, D., M. White, Y. Cheng, \& M. Tomlinson (1998). Restructuring the Employment Relationship. New York: Oxford University Press.

Green, F. (2005). Demanding Work: The Paradox of Job Quality in the Affluent Economy. New York, Princeton University Press.

Guillén, M. F. (1994). Models of Management. Work, Authority and Organization in a Comparative Perspective. Chicago and London: The University of Chicago Press.

Gustavsen, B. (2007). Work organization and 'the Scandinavian model'. Economic and Industrial Democracy, vol. 28, no. 4, 650-671.

Haagensen, K. M. (ed) (2011). Nordic Statistical Yearbook 2011. Nord 2011:11. Copenhagen: Statistics Denmark. 
Hall, P. A., \& D. Soskice (eds) (2001). Varieties of Capitalism: The Institutional Foundations of Comparative Advantage. Oxford: Oxford University Press.

Harrison, B. (1997). Lean and Mean. Why Large Corporations Will Continue to Dominate the Global Economy. New York/London: The Guilford Press.

Harvey, D. (2005). A Brief History of Neoliberalism. Oxford: Oxford University Press.

Hengeveld, R. (2012). Wasted World: How Our Consumption Challenges the Planet. Chicago: University Of Chicago Press.

Hernes, H. (1987). Welfare State and Woman Power. Oslo: Norwegian University Press.

Hvid, H., T. Bergholm, L. Gonäs, I. Juul, A. Kamp, J. Karlsson, A. Kasvio, L. Klemsdal, R. Salomon, \& E. Skorstad (2011). Nordic working life research-Continuity and renewal. Nordic Journal of Working Life Studies, vol. 1, no. 1, 3-21.

Johansson, A. L. (1989). Tillväxt och klassamarbete. En studie av den svenska modellens uppkomst. Stockholm: Tiden.

Jonung, L., \& T. Hagberg (2005). How costly was the crisis of the 1990s? A comparative analysis of the deepest crises in Finland and Sweden over the last 130 years. European Economy. Economic Papers 224.

Kalleberg, A. L. (2001). Organizing flexibly: The flexible firm in a new century. British Journal of Industrial Relations, vol. 39, no. 4, 479-504.

Karlsson, J. Ch. (2007). For whom is flexibility good or bad? An overview. In B. Furåker, K. Håkansson \& J. Ch. Karlsson (eds), Flexibility and Stability in Working Life. Basingstoke: Palgrave Macmillan, 18-29.

Katz, D., \& R. L. Kahn (1978). The Social Psychology of Organizations. New York: John Wiley \& Sons.

Knights, D., \& H. Willmott (2000). The Reengineering Revolution. Critical Studies of Corporate Culture. London: Sage Publications.

Kunda, G. (1992). Engineering Culture: Control and Commitment in a High-Tech Corporation. Philadelphia: Temple University Press.

Lawrence, P. R., \& J. W. Lorsch (1967). Organization and Environment. Boston: Harvard Business School.

Lilja, K. (1992). Finland: No longer the Nordic exception. In F. Anthony \& R. Hyman (eds), Industrial Relations in the New Europe. Oxford: Basil Blackwell, 198-217.

Lindbeck, A., et al. (1993). Options for economic and political reform in Sweden. Economic Policy, October, 219-263.

Maurice, M., F. Sellier, \& J. J. Silvestre (1982). Politique d'education et organization industrielle en France et en Allemagne. Paris: PUF.

Monden, Y. (1983). Toyota Production System. Practical Approach to Production Management. New York: Industrial Engineering and Management Press.

Mossé, P. R. (2009). Combining flexibility and workers' motivation: Lessons from a study on Italian and French hospitals. In E. J. Skorstad \& H. Ramsdal (eds), Organizational Flexibility and the New Working Life. A European Perspective. Farnham: Ashgate.

NFS (2012). Framtidsdeklaration för ett hällbart arbetsliv - ekonomiskt, socialt och ekologiskt. Antagen på den nordiska fackliga kongressen i Ålesund, Norge 19. September.

Nilssen, T. (1984). Brukermedvirkning. Holdninger og praktisering. Trondheim: IFIM.

Nilssen, T., \& E. Skorstad (1986). Framveksten av en ny produksjonstenkning. Om sammenhengen mellom produksjonsstyring, lay-out og arbeidsvilkår. Oslo: Tano Aschehoug.

OECD (2011). Divided We Stand: Why Inequality Keeps Rising. Paris: OECD.

OECD (2012a). OECD Economic Surveys: European Union 2012. Paris: OECD.

OECD (2012b). Labour Force Statistics, Average annual hours actually worked per worker. http://stats.oecd.org/Index.aspx?DataSetCode=ANHRS (reading 01.02.2012).

Ohno, T. (1990). L'Esprit Toyota. Paris: Masson. 
Oinas, T., J. Nätti, T. Anttila, \& A. Mustosmäki (2012). The Nordic difference: Job quality trends in Europe 1995-2010. Nordic Journal of Working Life Studies, vol. 2, no. 4.

Oliver, N., \& B. Wilkinson (1992). The Japanization of British Industry. New Developments in the 1990s. Oxford, UK: Blackwell Publishers,

Parent-Thirion, A. (2011). Working Conditions in Europe in 2010-Towards Sustainable Work? Presentation at the Work Research Conference, Tampere, Finland, 3rd November.

Peters, T., \& R. H. Waterman (1982). In Search of Excellence. New York: Harper and Row.

Piore, M., \& Sabel, C. (1984). The Second Industrial Divide. New York: Basic Books.

Pollert, A. (1988). Dismantling flexibility. Capital and Class, vol. 34, Spring, 42-75.

Rose, M. (1975). Industrial Behaviour. Theoretical Development since Taylor. London: Allen Lane

Rose, M. (2009). The impact of flexibility on employee morale and involvement: Largesample findings for UK workplaces. In E. J. Skorstad \& H. Ramsdal (eds), Flexible Organizations and the New Working Life. A European Perspective. Farnham: Ashgate, 43-78.

Sandberg, Å. (1995). Enriching Production. Perspectives on Volvo's Uddevalla Plant as an Alternative to Lean Production. Brookfield, WI: Avebury.

Schmidt, V. (2002). The Futures of European Capitalism. Oxford: Oxford University Press.

Schonberger, R. (1986). World Class Manufacturing. The Lessons of Simplicity Applied. New York: The Free Press.

Sennett, R. (1999). Det fleksible menneske. Eller arbejdets forvandling og personlighedens nedsmeltning. Højbjerg: Hovedland.

Skorstad, E. (2002). Organisasjonsformer. Kontinuitet eller forandring. Oslo: Gyldendal Akademisk.

Skorstad, E. (2006). Lean production, conditions of work and worker commitment. Economic and Industrial Democracy, vol. 15, no. 1994, 429-455. Reprinted in Beynon, H., \& T. Nichols, The Fordism of Ford and Modern Management. Fordism and Post-Fordism. Vol. I. Cheltenham: Edward Elgar.

Skorstad, E. J., \& H. Ramsdal (2009). Organizational Flexibility and the New Working Life. A European Perspective. Farnham: Ashgate.

Smircich, L., \& G. Morgan (1982). Leadership: The management of meaning. The Journal of Applied Behavioral science, vol. 19, no. 1.

Smith, L. C. (2011). The New North: The World in 2050. London: Profile Books.

Spjelkavik, O., B. Hagen, \& K. Härkäpää (2011). Supported Employment i Norden. AFI-rapport, R2011:3. Oslo: Arbeidsforskningsinstituttet.

Steen, A. (1995). Welfare-state expansion and conflicts in the Nordic countries: The case of occupational health care. Scandinavian Political Studies, vol. 18, no. 3, 159-186.

Thompson, P., \& D. McHugh (2002). Work Organization. A Critical Introduction. Basingstoke: Palgrave.

Thorsrud, E., \& F. Emery (1970). Mot en ny bedriftsorganisasjon. Eksperimenter i industrielt demokrati, fra Samarbeidsprosjektet LO/NAF. Oslo: Tanum.

Wilthagen, T., and F. Tros (2004). The Concept of 'Flexicurity: A new approach to regulating employment and labour markets. Transfer, European Review of Labour and Research, vol. 10, no. 2, 166-186.

Womack, J. P., D. T. Jones, \& D. Roos (1990). The Machine That Changed the World. New York: Rawson Ass.

Womack, J. P., \& D. T. Jones (2003). Lean Thinking. Banish Waste and Create Wealth in Your Corporation. London: Simon \& Schuster. 


\section{End notes}

${ }^{1}$ This is a discussion based mainly on the work of Atkinson (1984) and includes for instance Pollert (1988), Fevre (2007), Gallie et al. (1998), Kalleberg (2001), Karlsson (2007), Rose (2009), Bradley et al. (2000), Bradley (2009), and Thompson and McHugh (2002).

2 The most well-known solution based on these two principles is "lean production" as described by Womack et al. (1990, 2003). The discussion of this particular solution goes, however, further back, as illustrated by Dohse et al. (1985), Schonberger (1986), Nilssen and Skorstad (1986), Oliver and Wilkinson (1992) and in a two-volume collection containing reprinted articles edited by Beynon and Nichols (2006). The concept used in these cases was not that of "lean," but a variety of others such as just-in-time, Toyotoism, Ohnoism (Coriat 1991), world-class manufacturing, but the phenomenon discussed was the same, that is, the innovative principles of the Toyota production system as described in Monden (1983) and Ohno (1990). The discussion on flexible organization based on discussions of structural characteristics in general is, however, a wider one; see for instance Burns and Stalker (1961), Lawrence and Lorsch (1967) and Mossé (2009).

3 This includes management-oriented texts such as Peters and Waterman (1982), Deal and Kennedy (1982) and critical discussions such as Kunda (1992) and Smircich (1982).

${ }^{4}$ This is, for instance, demonstrated in Ackroyd (2009), Becattini et al. (2009), Benton (1992), Best (1990), Brusco (1990), Capecchi (1990), Harrison (1997), Piore and Sabel (1984), and Skorstad (2002).

${ }^{5}$ A classic example is Katz and Kahn (1978); more recent works illustrating this reasoning is Sennett (1999). 